\title{
Modelling by Finite Element Analysis Method of Stress State Establishing for an Steel Alloy
}

\author{
Silviu Macuta, Mirel Istratescu \\ "Dunarea de Jos" University of Galati, Domneasca Street 47, Galati, Romania \\ e-mail:Silviu.Macuta@ugal.ro
}

\begin{abstract}
The paper presents some results about thetension state in samples subject to pure bending fatigue process. Numerical simulation based on finit elementmethod was used. The tension field induced by a verticaldeformation imposed at the sample ends was generatedon an original patented machine. The studies werecarried out on two steels currently used in pressurevessels industry. Experimental data are in good agreementwith the simulated ones.
\end{abstract}

\section{INTRODUCTION}

Developing mechanical constructions for the pressure vessels industry, aircrafts, construction equipment or shipbuilding calls for the investigation of the characteristics of the materials subject to a small number of tension loads cycles close to the material elasticity limit[1].

To get a deeper insight into some aspects related to damage process of the materials used in the machine manufacturing variably subject to pure bending, a universal testing machine was designed and patented[2].

The steels considered for the investigations were: OL50,10TiNiCr180 basically used for the construction of pressure boiler and vessels.

To analyze the pressure states at the given moment, under forced deformations subject to pure bending on the above universal machine, the FEM method was applied.

\section{REAL STRUCTURE DISCRETIZATION. DESCRIPTION OF FEM AND THE MODEL USED}

The real structure discretization process consists in replacing the given structure, which is continuous, by a discrete one which discontinuous and idealized. The study of to the given structure is substituted by an approach to the entire assembly of the finite elements as obtained from discretization. [3], Thus, the elastic element in Fig. 1, which represents the type of sample to be used for fatigue tests at high tensions and small number of cycles, has the shape of a plate.

The finite element used is an iso parametric rectangular thick shell of six degrees of freedom across each node, and 24 degrees of freedom across an element which simulates the membrane and bending plate effects. The sides of the quad element are straight, a disadvantage eliminated by a fine discretization in the curvature radius area. Across the thickness five surface layers(Fig. 2) were considered by a suitable modeling of the tension field and the surface layer in the $\mathrm{Z}$ direction.
The finite element model considers the displacement field as the main unknown parameter and assembling the structure finite elements results in a lineal algebraic problem of generalized nodal displacement unknown parameters.

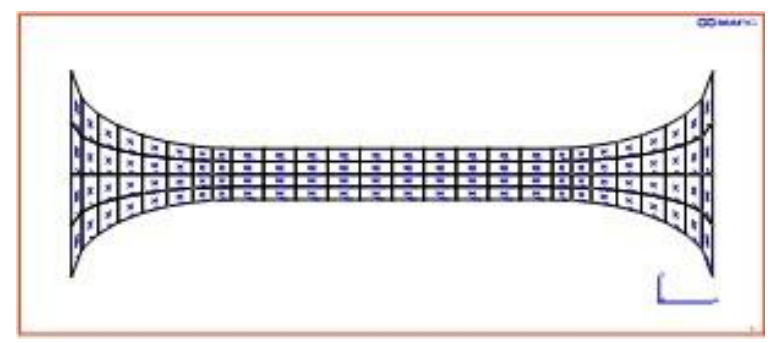

Fig 1. The elastic element

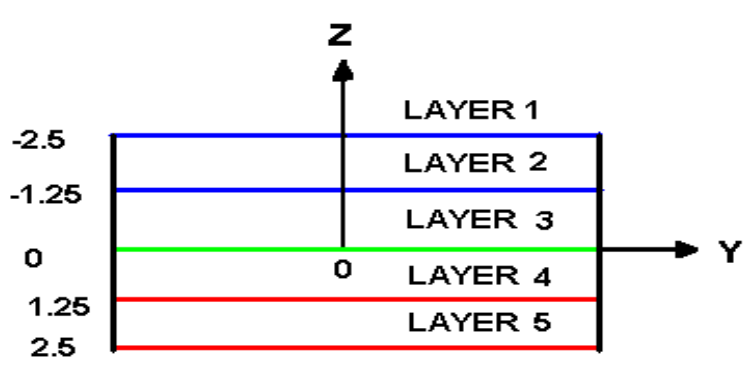

Fig 2.

The model used is considered is the one illustrated in Fig. 3 of the following boundary conditions; free displacement and rotations blocked $\mathrm{d}_{\mathrm{y}}=0, \mathrm{r}_{\mathrm{x}}=0, \mathrm{r}_{\mathrm{z}}=0$ and forced/imposed displacement $d_{z}$ (implicity angle $\alpha)$ at the fixing ends.

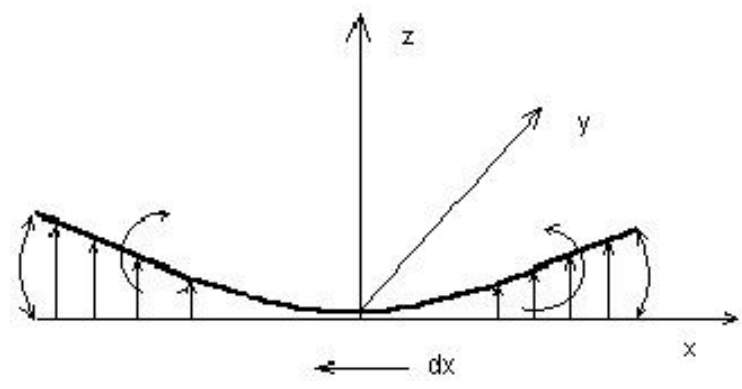

Fig 3. Illuatration of the model used 
The materials used for the samples have the features given in Table 1. [4] [5]

To make the appropriate calculations by the FEM method the program MARC version 6.2 was used.

TABLE 1.

\begin{tabular}{|l|l|l|l|}
\hline Steel & $\begin{array}{l}\sigma_{\mathrm{c}} \\
{[\mathrm{MPa}]}\end{array}$ & $v$ & $\begin{array}{l}\mathrm{E} \\
{[\mathrm{MPa}]}\end{array}$ \\
\hline OL 50 & 210 & 0,30 & $2,10 \cdot 10^{5}$ \\
\hline $\begin{array}{l}\text { 10TiNiCr18 } \\
0\end{array}$ & 205 & 0,26 & $1,93 \cdot 10^{5}$ \\
\hline
\end{tabular}

Data pre - and post processing was carried out by MENTAT II 1995 program. The operating system is HP UNIX 10.10 installed on a work station HP 712 of processor PA RISC 9000. The program is provided by the company MARC Analysis Research Corporation, California, USA, tested and recommed by Germanischer Lloyd and Technical University from Germany and Holland [6].

After running the program for the two types materials, for the imposed deformations the max sample tensions were obtained under the yieding limit at pure bending static load. The results are given in Table 2.

TABLE 2.

\begin{tabular}{|l|l|l|l|l|l|l|}
\hline $\begin{array}{l}\mathrm{N} \\
\mathrm{o}\end{array}$ & \multicolumn{2}{|l|}{$\begin{array}{l}\text { Steel A [OL50] } \\
\mathrm{E}=2,1 \cdot 10^{5}[\mathrm{MPa}]\end{array}$} & \multicolumn{2}{l|}{$\begin{array}{l}\text { Steel B [10TiNiCr 180] } \\
\mathrm{E}=1,93 \cdot 10^{5}[\mathrm{MPa}]\end{array}$} \\
\hline & $\begin{array}{l}\sigma_{\max } \\
{[\mathrm{MPa}]}\end{array}$ & $\mathrm{z}$ & $\begin{array}{l}\alpha \\
{[\mathrm{grad}} \\
{[\mathrm{mm}]}\end{array}$ & $\begin{array}{l}\sigma_{\max } \\
{[\mathrm{MPa}]}\end{array}$ & $\mathrm{z}[\mathrm{mm}]$ & $\begin{array}{l}\alpha \\
{[\mathrm{grad}]}\end{array}$ \\
\hline 1 & 230 & 0,84 & 1,84 & 150 & 0,6 & 1,31 \\
\hline 2 & 250 & 0,91 & 2 & 170 & 0,68 & 1,48 \\
\hline $\mathbf{3}$ & $\mathbf{2 7 0}$ & $\mathbf{0 , 9 9}$ & $\mathbf{2 , 1 6}$ & $\mathbf{1 9 0}$ & $\mathbf{0 , 7 6}$ & $\mathbf{1 , 6 6}$ \\
\hline
\end{tabular}

The paper presents the tension states at pure bending load for one sample only, at an imposed deformation, of alloyed steel currently used for the pressure vessels manufacture. Figures 4-6 illustrate the results of the FEM analysis for the alloyed steel OL50 (for 3 layers) as follows: fig. 4 shows the displacements over direction $\mathrm{z}$, fig. 4.1 shows the axial tensions at the surfaces compression(layer 1), fig. 4.2 - detail from 4.1 for the area concerned, fig. 4.3 - the values of the network nodes for tensions $\sigma_{X}=\sigma_{11}$, fig.5.1 and 5.2 present elongation values $\sigma_{X}=\sigma_{11}$ at $\mathrm{z}=2,16 \mathrm{~mm}$ (layer2) and finally fig. 6.1 and 6.2 the elongation tension on the inner face(layer 3 ). For all the other cases of imposed deformations of the two types of steels given in Table 2 the same variations laws of the normal tensions $\sigma_{X}=\sigma_{11}$ in the element layers.

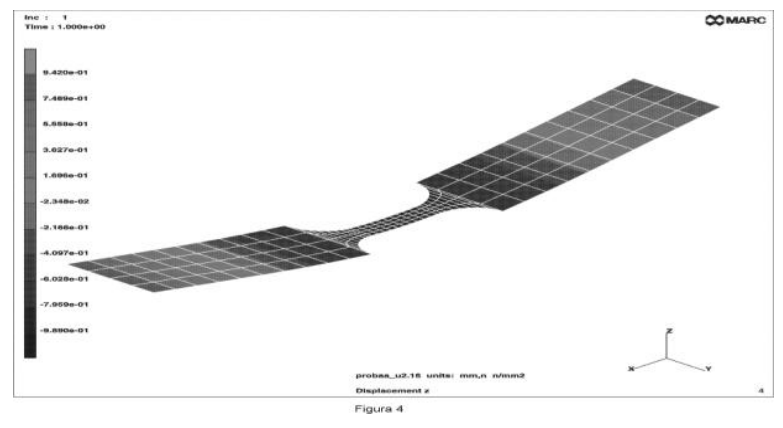

Fig 4. Displacement over directions

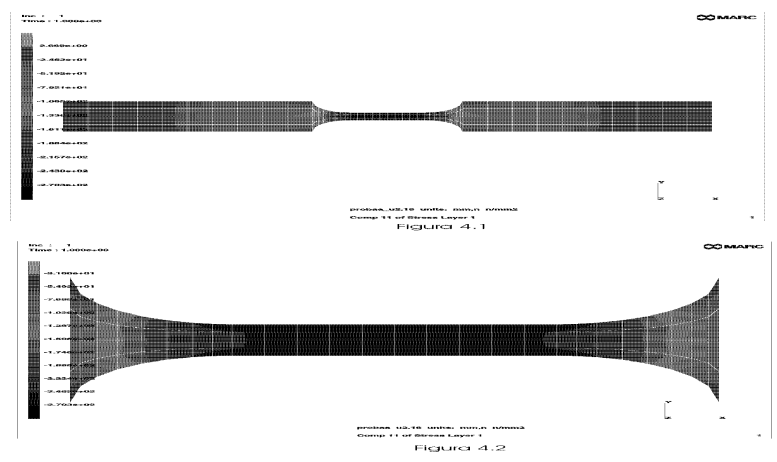

Fig 4.1 and 4.2 Axial tensions at the surfaces compression

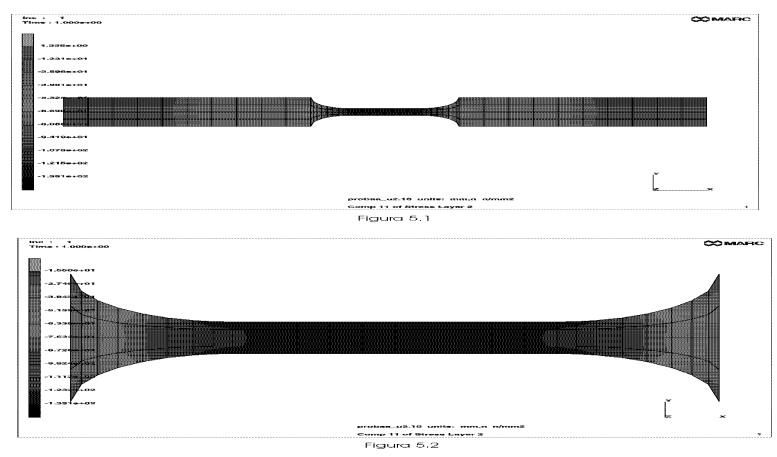

Fig. 5.1 and 5.2 Elongation values

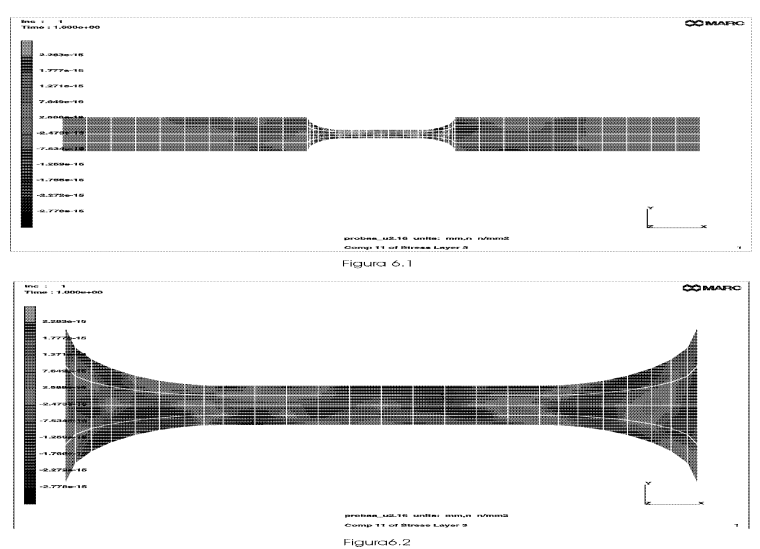

Fig. 6.1 and 6.2 The elongation tension on the inner face

\section{CONCLUSION}

From the analysis of figs 4-6 it can be seen in the area concerned tensions are uniform over a stress layer while linearly varying across the layer thickness(the Navier model of tension distribution is complied with). 


\section{REFERENCES}

[1] Karpenko, G.W, Malotiklovaia ustalost' stali v rabocih sredah, Izd. Naukova Dumka, Kiev, 1977, p. 5-105.

[2] Crudu, I., Măcuță, S., Maşina universală de incercat materiale, Patent Machine 102714 / 1991.

[3] Macuta, S., Thesis Ph.d., Univesity"Dunarea de jos"of Galati, Galati, 1999.
[4] Chesa, I., Alegerea şi utilizarea oţelurilor, Ed. Tehnică, Bucureşti, 1977, p. 25-35.

[5] Ştefănescu, I., Măcuță, S., Materiale utilizate în construcţia instalaţiilor şi utilajelor specifice industriei alimentare şi frigorifice. Tome I, University "Dunarea de jos" of Galați, Galati, 1996, p. 40-65

[6] *** User Manual for Marc-Mentat Analysis Research Corporation, California, USA1999 